\title{
Biological Effects of Electromagnetic Waves: Case Studies and Safety Standards
}

\author{
Harshul Thakur* and Deepika Sahu \\ School of Electronics and Electrical Engineering, Lovely Professional University, Phagwara - 144411, \\ Punjab, India;harshul.thakur2007@gmail.com, deepikasahu98279@gmail.com
}

\begin{abstract}
Objective: The purpose of writing this paper is to get knowledge about the electromagnetic fields, their applications and the most important i.e. to know about the biological effects of electromagnetic waves and the safety standards. Method: For to study about the adverse effects, several case studies have been included, each case study is based upon some experimental approach executed by different researchers. To calculate exposure level on tissue of human body, SAR measurement and FDTD method is introduced. This also describes the safety standards, as the research is done by various researchers and the organizations like FCC, ICNIRP, IEEE, CENELEC, AS/NSZ, NISV and NRPB etc., they have defined the maximum expectable exposure levels for protection of human health. Result: The results are found about thermal effect on human head, biological changes or imbalances, DNA changes etc. For resolving these problems, power radiation standards have been defined to minimize the possible health hazards.
\end{abstract}

Keywords: EIRP (Equivalent Isotropically Radiated Power), NIEMR (Non Ionizing Electro Magnetic Radiations), MW(Microwave),SAR (Specific Absorption Rate)

\section{Introduction}

The wireless technology provides wireless connection to the wireless devices. Wireless communication links provides point to point or point to multipoint connectivity for sending and receiving of text, voice, image and other kind of information. The most common wireless technologies used by people includes mobile phone, Wi-Fi, FM radio, Television broadcast stations, Satellite, Radar etc. The feasibility of above said technologies is due to the range of frequencies increasing from Extra low frequencies to Ultra high frequencies available in electromagnetic spectrum. This EM spectrum includes ionizing and non-ionizing radiations. The Figure 1 shows electromagnetic spectrum signifying frequency range of Ionizing \& Non-Ionizing radiations.

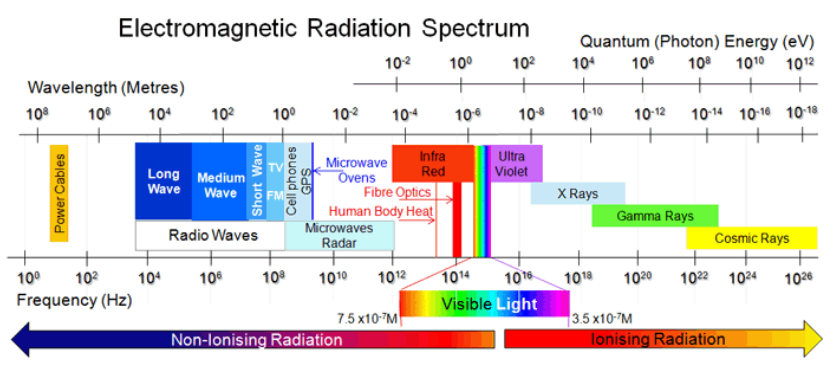

Figure 1. Electromagnetic spectrum representing NonIonizing and Ionizing Radiation along with frequencies and wavelength .

\section{Ionizing and Non-lonizing Radiations}

The energy of Non-Ionizing radiation has less than 
ionizing radiation. The non-ionizing radiations are found in a frequency ranging from 1 to 1000'sof $\mathrm{THz}$ which includes extremely low frequency(ELF), Microwave(MW), Infrared(IR), Visible light(VL) and Ultra-Violet light(UV)]. NIEMR has enough energy to excite the molecules and atoms to vibrate but not have enough energy to break chemical bonding. On the other side ionizing radiation can cause damage to living atoms/ molecules and also have tendency to remove electrons from an atom. The Ionizing radiations have frequency ranging from $1 \mathrm{PHz}$ (peta hertz) to $10 \mathrm{ZHz}$ (zeta hertz).

\section{Thermal and Non Thermal Effects}

As along with advancement of wireless technology, the level of EM Frequency from sources has risen in an exponential way. The Table1 shows the present status of power exposure in India as per the report given by Inter Ministerial Committeef.

The thermal effects are referred to as heat generated due to absorption of EM radiations. Most of the heating effect occurs at the head surface during cell phone usage and causes the temperature to increase. This excess heat is disposed by brain blood circulation by increasing the blood flow but the cornea of eye don't have this heat deposition system thus it leads to increase in temperature and cause harmful effect for eyes. The Non-thermal effects are possibly harmful for the biological cells of the human body. The mobile users have reported several symptoms ranging from tingling sensations to burning of skin, dizziness, loss of memory, heart palpitation, ear pain and headache etc. Radiated power by Radio frequency sources is displayed in Table1.

Table 1. Radiated power by radio frequency sources

\begin{tabular}{|l|l|c|c|}
\hline S. No. & $\begin{array}{l}\text { R.F. } \\
\text { Source }\end{array}$ & $\begin{array}{l}\text { Transmission } \\
\text { Power }\end{array}$ & Operating Frequency \\
\hline 1 & $\begin{array}{l}\text { Mobile } \\
\text { Phones }\end{array}$ & $1 \mathrm{~W}$ & GSM-1800/CDMA \\
\cline { 3 - 4 } & $\begin{array}{l}\text { Cell } \\
\text { Towers }\end{array}$ & $20 \mathrm{~W}$ & $800,900,1800,2450 \mathrm{Mhz}$ \\
\hline 3 & WI-FI & $10-100 \mathrm{~mW}$ & $2.4-2.5 \mathrm{Ghz}$ \\
\hline 4 & $\begin{array}{l}\text { TV } \\
\text { Tower }\end{array}$ & $10-500$ watt & $48 \mathrm{Mhz}-814 \mathrm{Mhz}$ \\
\hline 5 & $\begin{array}{l}\text { AM/FM } \\
\text { Tower }\end{array}$ & 1 KW-300Kw & $540 \mathrm{Khz}-108 \mathrm{Mhz}$ \\
\hline
\end{tabular}

It is also being observed that EM energy without heat did not affect or destroy the microorganisms. To prove this a continuous experiment is developed to segregate the thermal and Non-thermal effects. This process consists of exposing food to EM energy and maintains the temperature by removal of thermal energy by efficient heat exchanger. The temperature of $35^{\circ} \mathrm{C}$ has maintained and exposing time was of around three to eight minutes .

\section{Biological Effects}

The biological systems get more affected due to deep penetration of the electromagnetic waves in living tissues. The effects such as Parkinson's disease, cancer, alteration in the gene expression, multiple sclerosis and also observed an effect on neurological cellsf. Heating effects generated by the Radio Frequency radiation scan be the source of biological damage 月. It also causes displacement of electrolytes and ions within the body which origin interference to neurological system of the body and weakens the body defense mechanism? The cause of these biological effects is due to the amount and distribution of the energy absorbed in a biological object, which can further be described in conditions of the measuring Specific Absorption Rate (SAR). It is used to compute the absorption of energy which is described in watts per unit mass $(\mathrm{W} / \mathrm{kg})$. Generally a normal male has a height of $1.75 \mathrm{mor}\left(5^{\prime} 8^{\prime \prime}\right)$, mass of $70-75 \mathrm{~kg}$ or 165.3 pounds and surface area of total $1.85 \mathrm{~m}$. For example, if the total expose power on man's body is $10 \mathrm{~W}$ then the complete body SAR is $0.13 \mathrm{~W} / \mathrm{Kg}$. The Finite Difference Time Domain is another method which is also adopted to determine the SAR levels and Induced current (I) in a human model and it is found to be very useful for near field and far field exposures. In FDTD, the electric field and magnetic field is calculated using Maxwell equations. For measurement, exposed part of the body is divided into small cubic cells but larger in number (for better results cell dimensions should less than $1 / 10^{\text {th }}$ of the $\lambda$, wavelength):

The SAR is related to the internal E-field by

$$
\mathrm{SAR}=\frac{\sigma|\mathrm{E}|^{2}}{2 \rho} \frac{\mathrm{W}}{\mathrm{kg}}
$$

where, $\sigma$ is the conductivity (in $\mathrm{Sm}^{-1}, \rho$ is mass density (in $\mathrm{kg} \mathrm{m}^{-3)}$ and $\mathrm{E}$ is rms value of electric field strength $\mathrm{V} \mathrm{m}^{-1}$. 
The SAR value will also depend on the mathematical shape of the part of the body which is exposed to the RF energy.

$S A R=\int \frac{\sigma(\mathrm{r})|\mathrm{E}(\mathrm{r})|^{2}}{\rho(\mathrm{r})} \mathrm{dr}$

Thus tests have to be on each specific RF sources, such as a mobile phone and at the proposed position of use.

SAR is also described in relation to the temperature increment at a spot by

$\mathrm{SAR}=\frac{\mathrm{c} \Delta \mathrm{T}}{\Delta \mathrm{t}}$ at $(\mathrm{t}=0)$

where, $\Delta \mathbf{T}$ is the temperature change (in ${ }^{\circ} \mathrm{C}$ ) , $\Delta \mathrm{t}$ is the exposure duration (in sec), $\mathbf{c} \mathbf{c}$ is the specific heat capacity (in $/ / \mathrm{Kg}{ }^{\circ} \mathrm{C}$ ) io.

\section{Effects of Cell Phone Radiations on Human Cognitive Functions}

As the estimates provided by the Department of Economic and Social Affairs of United Nations, the statistics suggested that in 2017, the mobile phone users will reach to the population of 4.8 billion and expected to be 5 billion by 2019 in the world, which is approximated to be $67 \%$ of the earth population . Human cognitive functions are related to; the power of understanding, retain memory for long period of time, ability to learn new things and time required to act or respond. Investigators has reported that exposure of cell phone radiation can affect such cognitive functions or mental processes of human. Even to analyze this truth several tests may be considered like short term memory test, information manipulation test, response reaction time test before and after the exposure of cell phone radiation 1 . A study had reported that exposure to cell phone radiation of $915 \mathrm{MHz}$ affects the choice reaction time in particular of the human ${ }^{\text {I }}$. It is explored that human shows a faster response in simple reaction time and choice reaction time by exposing to $900 \mathrm{MHz}$ of EM radiation ${ }^{\text {I }}$. In one experiment, subjects were exposed to cell-phone field for30 minutes. The result shows the considerable differences between the attention level and the calculation speed in the serial subtraction

\section{Background Studies}

In this paper few and important case studies have been included to summarize the harmful effects, found or observed by the various authors on biological system, due to recent development in technologies.

\subsection{Case Study 1}

In this study the female mice were exposed to $2.45 \mathrm{GHz}$ of electromagnetic field for duration of 2 hour/day for a period of 30 days with power density of $0.1250 \mathrm{~mW} \mathrm{~cm}^{-2}$. It is found that MW radiations of frequency $2.45 \mathrm{GHz}$ produced adverse effects like abnormal embryonic development and increase damage of DNA in brain cells 1 . It is found that long term exposure of microwave radiation may amend implantation situation which may direct to abnormal pregnancy. The possible reasons for DNA cell breakdown first is due to slow down damage repair process of DNA and Fenton reaction initiated due to magnetic field generated by MW radiation which leads to breakage in DNA strands

\subsection{Case Study 2}

The electromagnetic fields released by the power transmission lines and other home used electronic appliances, it is realized that the electric component is not harmful, because it is attenuated by the metal present in building construction and by the plants/tree present near around of home place. So, magnetic component is the possible source of health hazard if any. Due to magnetic field exposure current induced in the human body and start flowing through the tissues of the body. It is more effecting to the linemen working on or nearby the high power transmission lines. As in neurological system of the body, currents are flowing from one nerve cell to other nerve cell, these currents may add up to the externally generated currents due to magnetic field and thus produce adverse effects. The tissues containing large amount of water like blood vessels and brain absorbed more EM radiations and it can cause serious health effects like deep tissue burn, headache, anxiety and even death

\subsection{Case Study 3}

To know about the thermal effects, cause due to the 
exposure of EM radiations experiment is executed ${ }^{10}$ to investigate heat transport mechanism in the Anterior Chamber of Rabbit Eye under exposure of power $50 \mathrm{~mW} /$ $\mathrm{cm}^{2}$ and $150 \mathrm{~mW} / \mathrm{cm}$. Author founds that at exposure of 20seconds with $50 \mathrm{~mW} / \mathrm{cm}$ 月 of power density, heat flow is dominant. But when exposed to $150 \mathrm{~mW} / \mathrm{cm}$ 月, it shows that heat transferred from vicinity of cornea to anterior chamber of the eye. The interaction between the cornea and millimeter waves is quite complex but it revealed that temperature near the cornea is more than the temperature near the lensto

\subsection{Case Study 4}

It is verified that the greater the frequency the more superficial is the absorption. The mathematical application is exhibited in the study that the eyes, regardless of their small volume absorb significant incident EM radiation especially when the antenna is placed in front of the human head. As the size of the head is reduced, especially in children using mobile phones are more prone to these radiations?

\subsection{Case Study 5}

Mobile phone devices operating on $<1 \mathrm{~W}$ and use Radio Frequency energy to emit EM radiation. As young people are using mobile phones for an elongated duration there is more risk of exposure to harmful EM radiations. This study is conducted to measure the temperature increase at ear region of the face. The proximity of the device near to ear was considered. The method like Infrared Thermal Imaging module was utilized to decide the exposure level to radiation. Cell phone devices with SAR values of 1.4 and 0.41 were used for experimentation purpose. The 8 humans of the age ranging from 18 years to 23 years were asked to talk on the cell phone for 10 minutes with and without headset. Before and after radiation exposure, thermal images were taken and a comparison was done using IR camera control and analysis software for research and science applications. After experimentation, it is found that the right ear surface temperature got rise of $0.3^{\circ} \mathrm{C}$ in comparison to the surface temperature value of the left ear. With headphone usage the surface temperature rise was observed in both ears $\mathrm{H}^{2}$ By considering different frequency ranges and system SAR is calculated in Table 2 .
Table 2. Shown the maximum acceptable exposure levels for protection of human health

\begin{tabular}{|c|c|c|c|c|c|c|}
\hline \multirow[t]{4}{*}{ Country } & \multirow{4}{*}{$\begin{array}{c}\text { In } \\
\text { Year }\end{array}$} & \multirow[t]{4}{*}{ Organization } & \multicolumn{4}{|c|}{ Frequency in $\mathrm{MHz}$} \\
\hline & & & 1800 & 900 & 1800 & 900 \\
\hline & & & \multirow{2}{*}{\multicolumn{2}{|c|}{$\begin{array}{c}\text { Power } \\
\text { Density, in } \\
\text { Watts } / \mathrm{m}^{2}\end{array}$}} & \multirow{2}{*}{\multicolumn{2}{|c|}{$\begin{array}{c}\text { Electric } \\
\text { Field, in } \mathrm{V} / \mathrm{m}\end{array}$}} \\
\hline & & & & & & \\
\hline Hungary & 1986 & HUNGARY & 0.1 & 0.1 & 6.1 & 6.1 \\
\hline UK & 1993 & NRPB & 100 & 33 & 194 & 112 \\
\hline Europe & 1995 & CENELEC & 9.0 & 4.5 & 58.1 & 41.1 \\
\hline Germany & 1998 & ICNIRP & 9.0 & 4.5 & 58.3 & 41.25 \\
\hline Australia & 1998 & AS/NSZ & 2.0 & 2.0 & 27.5 & 27.5 \\
\hline Austria & 1998 & Salzburg & 0.001 & 0.001 & 0.6 & 0.6 \\
\hline Italy & 1998 & Italy & 1.0 & 1.0 & 20 & 20 \\
\hline $\begin{array}{l}\text { Switzer- } \\
\text { land }\end{array}$ & 1999 & NISV & 0.1 & 0.04 & 6 & 4 \\
\hline USA & 1999 & FCC/IEEE & 12 & 6 & 67.3 & 47.6 \\
\hline
\end{tabular}

\section{Safety Standards}

The government of different countries adopts safety standards to protect population living nearby BST (Base Station Transceiver) and Humans using mobile phones. Many national and international standards were purposed but standards given by International Commission on Non-Ionizing Radiation Protection (ICNIRP) are followed by more than 80 countries worldwide F $^{\text {? }}$ They purposed different standards for general population and different for occupational population. Many government bodies have also advised the telecomm service provider companies to share the antenna for their Tele-coverage which will reduce the EM exposure. In US, as per FCC (Federal Communications Commission) the SAR level of mobile should be higher than 1.6 watts/kg over the mass of $1 \mathrm{~g}$ of tissue whose absorption rate is higher in the body. In Europe, CENELEC (European Committee for Electro technical Standardization) has declared that SAR level of the cell phones or other electronic devices should not exceeds more than $2 \mathrm{~W} / \mathrm{kg}$ over the mass of $10 \mathrm{~g}$ of tissue of human body. Similarly in India, TEC(Telecommunication Engineering Center) is only rely on the SAR limits as standardized by US but also lab test held on the mobile phones and around 10\%of BTS. The TEC is responsible for standardization after trials on new technologies then after the approved test certificates issued to the particular service providerst 
One of the agency of World Health Organization (International Agency of Research on Cancer) has classified RF electromagnetic field to be carcinogenic (could be some risk) to humans lying in Group 2B in the

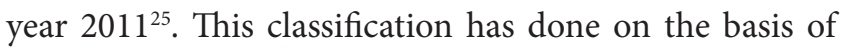
evidence achieved from many epidemiological studies to revel the relation between the mobile usage and brain tumor. A study conducted by IARC in collaboration with 13 countries and the results leads to the classification of Group 2B

Many of the prominent organizations have given standards and guideline. The organization are FCC, ICNIRP, IEEE, CENELEC, AS/NSZ, NISV and NRPB and the intention of these organizations to standardize the exposure limits so to protect human health, against established adverse effects induced by exposure EM radiation of frequencies at $900 \mathrm{Mhz}$ and $1800 \mathrm{Mh}$ 年 maximum acceptable exposure levels for protection of human health is defined in Table 3.

India follows the guidelines given by ICNIRP for to limit the EM radiation exposure due to telecom service providers in Table 4.

Some reference level standards are given by ICNIRP用 that is termed in Table 5.

As such RF exposure level胢 is measured in some big citiesand that are tabulated in Table 6.

Table 3. Guidelines given by ICNIRP

\begin{tabular}{lcc}
\hline Type of Exposure & \multicolumn{2}{c}{ General Public } \\
\hline Frequency Range & $400-2000 \mathrm{Mhz}$ & $2-300 \mathrm{Ghz}$ \\
Power Density $(\mathrm{W} / \mathrm{m})$ & $\mathrm{f} / 200$ & 10 \\
Magnetic Field Strength $(\mathrm{V} / \mathrm{m})$ & $0.0037 \mathrm{f} 1 / 2$ & 0.16 \\
Electric Field Strength $(\mathrm{A} / \mathrm{m})$ & $1.375 \mathrm{f} 1 / 2$ & 61 \\
\hline
\end{tabular}

Table 4. Limitations for the main telecommunication services and systems, ICNIRP f $^{\text {s }}$

\begin{tabular}{|l|l|c|c|c|}
\hline $\begin{array}{l}\text { Frequency } \\
\text { Range(MHz) }\end{array}$ & System/ Services & $\begin{array}{c}\text { Localized SAR (Trunk } \\
\text { and Head) W/kg }\end{array}$ & $\begin{array}{c}\text { Localized SAR } \\
\text { (Limbs) W/kg }\end{array}$ & $\begin{array}{c}\text { Average SAR (Whole } \\
\text { Body) W/kg }\end{array}$ \\
\hline $1850-1900$ & PCS 1900 & 2 & 4 & 0.08 \\
\hline $1710-1880$ & PCS 1800 & 2 & 4 & 0.08 \\
\hline $890-960$ & Mobile Telephony 900Mhz & 2 & 4 & 0.08 \\
\hline $824-894$ & Mobile Telephony 800Mhz & 2 & 4 & 0.08 \\
\hline $806-869$ & Trunking 800Mhz & 2 & 4 & 0.08 \\
\hline $407-806$ & UHF TV & NA & NA & 0.08 \\
\hline $174-216$ & VHF TV & NA & NA & 0.08 \\
\hline $54-88$ & & NA & NA & 0.08 \\
\hline $88-108$ & FM Broadcast & NA & NA & 0.08 \\
\cline { 3 - 5 }
\end{tabular}

Table 5. Reference levels for tele-communication, ICNIRP年

\begin{tabular}{|c|c|c|c|c|c|}
\hline $\begin{array}{l}\text { Frequency } \\
\text { Range(MHz) }\end{array}$ & $\begin{array}{l}\text { System/ } \\
\text { Service }\end{array}$ & $\begin{array}{l}\text { Hrms } \\
(\mathrm{V} / \mathrm{m})\end{array}$ & $\begin{array}{l}\text { Erms } \\
(\mathrm{V} / \mathrm{m})\end{array}$ & \begin{tabular}{|r} 
SrmsF \\
field, \\
E-fielc
\end{tabular} & $\begin{array}{c}\text { Averaging } \\
\text { time } \\
{[\mathrm{E}]^{\wedge} 2} \\
{[\mathrm{H}]^{\wedge} 2}\end{array}$ \\
\hline $1850-1900$ & PCS 1900 & - & - & 9.38 & 30 \\
\hline $1710-1880$ & PCS 1800 & - & - & 8.98 & 30 \\
\hline $890-960$ & $\begin{array}{l}\text { Mobile } \\
\text { Telephony } \\
\text { 900Mhz }\end{array}$ & - & - & 4.63 & 30 \\
\hline $824-894$ & $\begin{array}{l}\text { Mobile } \\
\text { Telephony } \\
\text { 800Mhz }\end{array}$ & - & - & 4.3 & 30 \\
\hline $806-869$ & $\begin{array}{l}\text { Trunking } \\
800 \mathrm{Mhz}\end{array}$ & - & - & 4.19 & 30 \\
\hline $174-216$ & VHF TV & 0.07 & 27.5 & 2 & 30 \\
\hline $54-88$ & & 0.13 & 27.5 & 6.27 & 30 \\
\hline $88-108$ & $\begin{array}{l}\text { FM } \\
\text { Broadcast }\end{array}$ & 0.08 & 27.5 & \begin{tabular}{|l|l|}
2.14 & 2
\end{tabular} & 30 \\
\hline
\end{tabular}

Table 6. Maximum measured RF level in North Indian big cities

\begin{tabular}{llc}
\hline \multicolumn{3}{l}{ Maximum RF level in North India } \\
\hline S. No. & Place & Max RF level Noted $\left(\mathrm{w} / \mathrm{m}^{2}\right)$ \\
\hline 1 & Delhi & 0.00762 \\
2 & Gurgaon & 0.00320 \\
3 & Chandigarh & 0.00400 \\
4 & Ambala & 0.00040 \\
5 & Panipat & 0.00075 \\
\hline
\end{tabular}

\section{Conclusion}

For each and every development of technology, high quality of communication services provided by the service provider, which increased the mischief level regard EM radiations. With the increment of facilities, hazards also increased simultaneously. In the above review of different studies and researches along with experiments done by 
the researchers make us came to know about the hilarious effects of EM radiation on children, brain, skin, eyes, thin pinnaofwomen as well as children. It not only effect human health but also harm to the environment and animals living around it.DNA strands as well as reproduction system of women can be affected by high exposure of EM radiation. In this paper along with providing information of the electromagnetic waves, the adverse effects in various case studies have been analyzed. Safety standards were discussed so that electronic equipments should work below the standard limits and don't cause any effects on the user's biological systems.

In the above described review of different research papers also defined the pollution level of some main cities of India, where radiation level was observed exceptionally high. After lot of controversial and complex experimental research upon potential health effects, some organizations are doing research upon reduction and prevention from more exposure of radiation. So that people must know about the cause, prevention method of exposure of EM radiation and must follow the standards given by the WHO, environmental health safety organizations, Russian and East European Countries research organizations, European and UK organizations etc. Some precautions are described above to make sure the limited exposure of EM wave.

\section{References}

1. Zamanian A, Hardiman C. Electromagnetic radiation and human health: A review of sources and effects.High Frequency Electronics;2005 Jul. p. 16-26.

2. Sharma RS, Duggal A, Jindal RN, Srivastava UK.Report of the inter-ministerial committee on emf radiation.

3. Banik S, Bandyopadhyay S, Ganguly S. Bioeffects of microwave--a brief review.Bioresource Technology. 2003; 87(1):155-9

4. Stavroulakis P. Biological effects of electromagnetic fields. Springer-Verlag Berlin Heidelberg; 2003.

5. Lavanya AB. Effects of electromagnetic radiation on biological systems: a short review of case studies. Electromagnetic Interference and Compatibility.8th International Conference onINCEMIC 2003; 2003. p. 87-90.

6. BBC.CO.UK. Mobile Phone Safety. [Internet].[cited 2008 Aug 18]. Available from: http://www.bbc.co.uk/science/ hottopics/mobilephones/safety.shtml.

7. RF Safe. What is RF Radiation? [Online].[cited 2008 Jul 31]. Available from:http://www.rfsafe.com/research/rf_radiation/what_is_rf/intro.htm.

8. Kitchen R. RF and Microwave radiation safety. Second Edition. Newnes; 2001.
9. Chen JY, Gandhi OP,Conover DL. SAR and induced current distributions for operator exposure to RF dielectric sealers. IEEE Transactions on Electromagnetic Compatibility. 1991 Aug; 33(3):252-61.

10. King RWP, Adair ER,Petersen RC. Comments on Biological effects of radio-frequency/microwave radiation.IEEE Transactions on Microwave Theory and Techniques. 2002 Aug;50(8):2032-3.

11. IEEE draft standard for safety levels with respect to human exposure to radio frequency electromagnetic fields, $3 \mathrm{kHz}$ to $300 \mathrm{GHz}$ - Amendment: Specifies Ceiling Limits for Induced and Contact Current, Clarifies Distinctions between Localized Exposure and Spatial Peak Power Density. IEEE Unapproved Draft Std PC95.1a/D1.4;2009 Jun.

12. Lin JC. Human exposure to RF, microwave, and millimeter-wave electromagnetic radiation [Health Effects]. IEEE Microwave Magazine. 2016 June; 17(6):32-6.

13. Lin JC. Mental process in humans and exposure to cell-phone radiation. IEEE Microwave Magazine. 2004 Dec;5(4):26-30.

14. Preece AW, Iwi G, Davies-Smith A, Wesnes K, Butler S, Lim E, Varey A. Effect of a $915-\mathrm{MHz}$ simulated mobile phone signal on cognitive function in man. International Journal of Radiation Biology. 1999;75:447-56.

15. Koivisto M, Krause CM, Revonsuo A, Laine M, Hamalainen $\mathrm{H}$. The effects of electromagnetic field emitted by GSM phones on working memory. Neuroreport. 2000; 11:16413.

16. Edelstyn N, Oldershaw A. The acute effect of exposure to the electromagnetic field emitted by mobile phones on human attention.Neuroreport. 2002; 13;.119-21.

17. Paulraj R, Behari J. Radiofrequency radiation effect on protein kinase C activity in rats' brain.2004; 545:127-30.

18. Singh VP. $2.45 \mathrm{GHz}$ low level $\mathrm{CW}$ microwave radiation affects embryo implantation sites and single strand DNA damage in brain cells of mice, mus musculus. ELECTRO '09. International Conference onEmerging Trends in Electronic and Photonic Devices and Systems, Varanasi; 2009. p. $379-82$.

19. Gandhi OP. Biological effects and medical applications of electromagnetic energy, Prentice Hall; 1990.

20. Koike A. An investigation of the heat transport mechanism under the millimeter-wave exposure considering the convection in the anterior chamber of rabbit's eye.URSI GASS; 2011.

21. Taki M. Assessment of possible health risks of electro-magnetic field exposures due to emerging technologies. Proceedings of 2013 URSI International Symposium onElectromagnetic Theory (EMTS), Hiroshima; 2013. p. 3-4.

22. Moneda AP, Ioannidou MP, Chrissoulidis DP. Radio-wave exposure of the human head: Analytical study based on a versatile eccentric spheres model including a brain core and a pair of eyeballs. IEEE Transactions on Biomedical Engineering. 2003 June; 50(6):667-7.

23. Parvathy CR, Hukeri M, Krishnan SN, Mariamicheal A, Chanu OR. Study of changes in surface temperature of facial region due to mobile phone radiation. 2015 Interna- 
tional Conference onInnovations in Information, Embedded and Communication Systems (ICIIECS), Coimbatore; 2015. p. 1-5.

24. International commission for non-ionizing radiation protection home page [Internet]. [cited 2008 Jan 7]. Available from: http://www.icnirp.org/.

25. Stringent mobile radiation standards come into force from tomorrow new mobile handsets to comply with SAR value of $1.6 \mathrm{w} / \mathrm{kg}$ - penalty, random checks introduced for enforcement. Press Information Bureau, Government of India [Internet]. 2012. [cited 2013 Dec 22]. Available from: http:// www.pib.nic.in/newsite/erelease.aspx?relid=87152.

26. International Agency for Research on Cancer. IARC classifies radiofrequency electromagnetic fields as possibly carcinogenic to humans.2011 May 31, Press Release No.208.
27. The Interphone study group. Brain tumours risk in relation to mobile telephone use: results of the Interphone international case control study. International Journal of Epidemiology. 2010;36:675-94.

28. Tanwar VS. Living dangerously in Indian cities: An RF radiation pollution perspective. 2006 Proceedings of the 9th International Conference onElectroMagnetic Interference and Compatibility (INCEMIC), Bangalore; 2006. p. 458-66.

29. Latin American experts committee on high frequency electromagnetic fields and human health. Scientific review non-ionizing electromagnetic radiation in the radiofrequency spectrum and its effects on human health. EduMed. 2010 Jun. p. 1-186. 